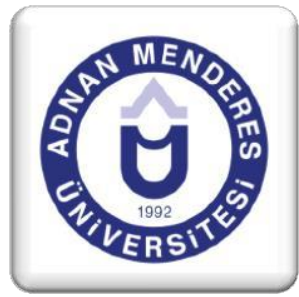

\section{Dördüncü Sınıf Öğrencilerinin Ceza ve Kural Kavramlarına İliş kin Algılarının Metaforlarla Analiz Edilmesi}

\author{
Tuba AKAR ${ }^{1}$, Ayşe Dilek ÖĞRETİR ${ }^{2}$
}

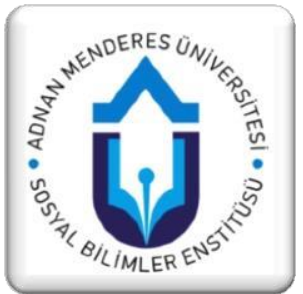

\title{
ÖZET
}

$\mathrm{Bu}$ araştırmanın amacı, İlkokul dördüncü sınıf çocuklarının ceza ve kural kavramlarına ait kullandıkları metaforları ortaya çıkarmaktır. Araştırma örneklemini Sinop merkezde iki (113 kız- 71 erkek) ve Korucuk ilçesi iki köy ilkokulunda (40 kız-35 erkek) olmak üzere toplam 259 öğrenci oluşturmaktadır. Araştırmada veri toplamak amacıyla, araştırmaya katılan çocukların ceza ve kural kavramlarına dair sahip oldukları algıları ortaya çıkarmak amacıyla açık uçlu bir anket formu düzenlenmiş; anket formunda çocuklara "Ceza............ gibidir; çünkü......." ve "Kural............. gibidir; çünkü......." cümlelerini tamamlamaları istenmiştir. Öğrencilerin ceza ve kural kavramlarına ilişkin düşünceleri içerik analizi tekniği ile çözümlenmiştir. Araştırma sonucunda, üretilen ceza metaforların kaynaklarına bakıldığında; engellenme (hapishane), balon, acı biber, spor, kötü gibi kavramların en çok kullanıldığı görülmüştür. Öğrenciler tarafından üretilen kural ile ilgili metaforların kaynaklarına bakıldığında ise trafik, okul, müzik, ev ve spor gibi kavramların öğrenciler tarafından en çok algılandıkları tespit edilmiştir. İlkokul 4.sınıf öğrencilerinin ceza ve kural kavramlarını soyut düşünemedikleri için yaşamsal olarak maruz kaldıkları deneyimler üzerinden ilişkilendirdikleri anlaşılmıştır. Ancak bu temel deneyimler üzerine çocuklara kavramsal şemalarını oluşturmaları adına kavramların fonksiyonlarına ilişkin formel bilgilere pek yer verilmediği bulunmuştur.

Anahtar Sözcükler: Kural, Ceza, Öğrenci, Metafor, İçerik Analizi

\section{The Analysis of the Perceptions of the Concepts of Punishment and Rule of the Fourth Grade Students in the Primary School with the Metaphors}

\begin{abstract}
The purpose of this research is to reveal the metaphors used by elementary school fourth grade children in relations to the concepts of punishment and rule. The sample of the research is composed of 261 students in two primary school in the central district of Sinop (113 girls and 71 boys) an done primary school in Korucuk town (40 girls and 35 boys). An open-ended questionnaire was prepared in order to reveal the perceptions of the children who participated in the research about the concepts of punishment and rule. In the questionnaire, the children were asked to complete following sentences: "The punishment look likes............."; "Because ....". The rule look likes .............; Because ... ". In order to examine the children's perceptions about punishment and rule, The researchers were used to content analysis technique. As a result of the research, the concepts such as frustration (prison), balloon, hot pepper, sport, bad, etc. were seen to be the most used concepts by the students for the punishment metaphors. When we look at the sources of the rule metaphors, the concepts such as traffic, music, home and sports, etc. the most used concepts were identified and perceived by the students. It has been understood that the fourth grade students in the primary school have associated the concepts of punishment and rule through their experiences which they are vital for the them because they can not think abstractly. However, it has been found that there is not much formal information about the functions of the concepts on the basis of these basic experiences and the basis of the child's conceptual schemas.
\end{abstract}

Keywords:Rule, Punishment, Student, Metaphor, Content Analysis, Turkey

\footnotetext{
${ }^{1}$ Öğretim Görevlisi Sinop Üniversitesi, Eğitim Fakültesi, Okul Öncesi Eğitim ABD, tubaakar80@gmail.com ${ }^{2}$ Doç. Dr. Gazi Üniversitesi, Eğitim Fakültesi, Temel Eğitim Bölümü Okul Öncesi Öğretmenliği ABD, ogretir@gazi.edu.tr,dilekogretir@gmail.com
} 


\section{Giriş}

Sosyal bir varlık olan insanın huzurlu bir şekilde yaşayabilmesi için kuralların ve düzenin varlığı ön koşullardandır. Bu gerekçelerden dolayı insanların toplu halde bulunduğu ve yaşadığ 1 her yere disiplin gereklidir (Bal, 2005:1). Bir toplumdaki kurumlarda, politikada, ailede, eğitimde kısacası her yerde çalışmaların ve yaşamın düzenli devam etmesi, disiplinin sağlanması da kuralların varlığına bağlıdır. TDK sözlüğünde kural "Bir sanata, bilime veya bir düşünce ve davranış sistemine temel olan yön veren ilke" şeklinde tanımlanmıştır.

Birey yaşama adım attığı okul öncesi dönemden itibaren yaşamın her alanında birtakım kurallarla karşılaşmakta ve kendisinden bu kurallara uygun davranışlar göstermesi beklenmektedir. Bireyin hayatının büyük bir kısmını geçirdiği eğitim kurumlarında da sınıf içinde veya okul içinde belirlenen kurallara uygun davranışlar göstermesi gerekmektedir. Etkili ve güvenli disiplinin pek çok yolu vardır. Bu yollardan en kestirme şekilde etkili bulunan ve en çok tercih edilen yöntemlerden biri cezalandırmadır (Mahiroğlu ve Buluç, 2003:3). "Ceza, öğretmenin öğrencinin istenmeyen davranışına karşıllk öğrenciyi hoşuna giden şeylerden alıkoyması ya da ögrencinin hoşuna gitmeyen işler yaptırmasıdır" (Korkmaz, 2003:184). Ceza, diğer yöntemler işe yaramadığında istenmeyen davranışa karşı kullanılacak en son yöntem olarak düşünülmelidir. Öğretmenlerin, ceza yöntemini kullanırken dikkatli olmaları gerekmektedir. Örneğin öğrencilere verilecek cezalar davranışla orantılı olarak o davranışın tekrarını engelleyecek şekilde uygulanmalı ve öğrenci kuralları net bilmeli, kurallara uymadığında alacağı cezanın sebebini iyice anlamalıdır.

Korkmaz (2003)'e göre ceza aşağıdaki çerçeveler doğrultusunda gerektiğinde uygulanabilir (303):

- İstenmeyen davranışların uyarılması

- İstendik davranışın açıklanması

- Uyarının kisa olması

- Ders düzenine dönerek istendik davranışta bulunan öğrencilere memnuniyetin belirtilmesi

- İstenmeyen davranışı gösteren öğrenci davranışını değiştirirse memnuniyetin belirtilmesi

Ercan (2004)'a göre ise çocukların kurallara uymadıkları zamanlarda onlara uygulanan ceza ve baskılar onlardaki disiplinsiz davranma sebeplerini ortadan kaldırmaz. Ayrıca çocuğun kurallara uymama eğilimi ile yetişkinlerin çocukların kurallara uymamasına gösterdikleri refleks çatıştığında çocuklarda bunalım, korku, tedirginlik ve sıkıntılar oluşturabilir. Bunun sonucunda çocuklar okul, ev ve sınıf düzenini zorlayacak davranışlar ortaya koyacaklar ve şartlar uygun olduğunda eski davranışlarını yenileyeceklerdir (Lewis, 2011).

Ceza, öz olarak disiplinden farklıdır ama varlığı disiplin kavramının kapsamına girer (Salk, 1998: 79). Çocukları disipline sokmak onlarla ilgilenildiğini gösterir. Çocuk hiç bir disiplin uygulamasının, kuralın olmayışını ilgi noksanlığı olarak yorumlayacaktır. Çocukların davranışlarıyla ilgili kuralların olmayışı, gelen tepkilerin niteliğindeki tutarsızlık onların endişeli olmasına yol açacaktır. Başka bir yönden ise "Cezanın verdiği üzüntü, kendi suçunu unutturacak kadar güçlüyse yanlı davranmış olduğu konusunda düşünmeye yönelecek yerde, cezayl vereni suçlayacaktır"(Salk,1998:86).

Tam olarak ailede, okulda ve toplumda kazandırılmak istenen davranışların öğrenilmesi sürecinde hedeflenen göstergelere sağlıklı bir şekilde ulaşılması çok önemlidir. Harter (2006) çocukların yaşamlarında orta ve geç çocukluk döneminde özellikle 8-11 yaşları arasında 
çocuklar kendilerini gittikçe daha fazla psikolojik karakteristik özelliklerle tanımlarlar (Harter, 2006: 526). Orta çocukluk döneminde çocuğun hayatında birçok yaşantı önemli izler bırakır (Giren, 2016). Sembolik unsurlar hayatımızın her yerinde yer almaktadır. Kullandığımız semboller bizim çevre algılarımız hakkında fikir vermektedir (Kaya, 2010). $\mathrm{Bu}$ sembollerden bir tanesi de nitel araştırmalarda yaygın olarak kullanılan metafor analiz yöntemidir. Bredeson (1985)'a göre (Akt. Örücü 2012:344) metaforlar gözlüğe benzer ve metafor gözlüğü aracılığı ile bireyin çevreyi nasıl anlamlandırdığını anlaşılır.

Metaforun tanımı TDK sözlüğünde "Bir kelimeyi veya kavramı kabul edilenin dışında başka anlamlara gelecek biçimde kullanma" şeklinde tanımlanmıştır. Tam bu noktada orta çocukluk dönemdeki çocukların ebeveyn ve öğretmenleri tarafindan onlara uygulanan kural ve ceza kavramlarına yükledikleri misyon ve verdikleri değer önemli görülmektedir (Guerreo, 2002). Öyle ki yapılan birçok çalışmanın bulguları ışığında çocuklarda kuralları ve cezaları içselleştirmenin kritik bir öneme sahip olduğu açıktır. Bu doğrultuda çocukların kurallara uyma, cezanın nedenselliğini anlama durumunda elde edecekleri kazanımlara bağlı öz farkındalıklarını destekleyen yaklaşımlar tavsiye edilmektedir (Martinez, et.al., 2001; Öğretir, 2017a). Tam da bu nedenlerle ebeveyn ve öğretmenlerin çocuğun gelişimi ve okula uyumu açısından sorumlulukları büyüktür. Sınıf ortamında eğitim hakkındaki metaforların eğitimle ilgili konularda yorum yapılabilmesini olanaklı kılan eğitim hakkındaki metaforlardır (Goatly, 2002; Perry ve Cooper, 2001). Murray ve Greenberg (2000)'e göre, öğretmenlerini ve anne babalarını duygusal açıdan tatmin edici ve yapıcı bulan çocukların, desteklenmeyen deneyimleri olan çocuklara oranla duyuşsal ve sosyal gelişim bakımından çevrelerine karşı daha olumlu tutum sergiledikleri görülmektedir. Tüm bu nedenlerle geleceğin sahipleri olan çocukların "ceza ve kural" kavramlarına ilişkin algıları MEB Okul Öncesi Eğitim ve İlköğretim Kurumlar Yönetmeliği, Öğretmen tutumları, Sınıf yönetimi, Öğretmenlerin kullandığı Öğretim Stratejileri, Yöntem ve Teknikleri açısından daha güvenli, daha huzurlu bir eğitim ortamı ile çocukların gelişimlerini destekleyici bir eğitim yapılanmasında ilgili kurumlara ve kişilere zengin bir veri kaynağı sağlar.

\subsection{Amaç}

Bu çalışmanın amacı, İlkokul dördüncü sınıf öğrencilerinin «Ceza ve Kural» kavramlarına İlişkin oluşturdukları metaforları toplamak ve toplanan bu metaforları çeşitli kategoriler altında sınıflandırarak İlkokul 4.sınıf öğrencilerinin algılama biçimlerini ortaya koymaktır.

Çalışmada, "İlkokul dördüncü sınıf öğrencilerinin «Ceza ve Kural» kavramlarına ilişkin kullandıkları metaforlar nelerdir?" sorusuna yanıt aranmıştır. Buna bağlı olarak şu alt soru değerlendirilmiştir: İlkokul dördüncü sınıf öğrencilerinin «Ceza ve Kural» kavramlarına ilişkin kullandıkları metaforlar hangi kategoriler altında toplanabilir?

\section{Yöntem}

\section{1. Çalışma Grubu}

Araştırma, Sinop merkezde yer alan iki ilkokul (113 kız-71 erkek) ve Korucuk ilçesinde yer alan iki köy İlkokulunda (40 kız-35 erkek) olmak üzere toplam 159 öğrenci ile yapılmıştır. Öğrencilerin 153'ü kı, 106'sını erkekler oluşturmaktadır. Tablo 1'de çalışma grubunun öğrenim gördükleri ilkokullara göre cinsiyet dağılımı gösterilmiştir.

\subsection{Araştırmanın Deseni}

Araştırmada nitel araştırma desenlerinden biri olan olgu bilim deseni kullanılmıştır. Olgu bilim deseniyle yapılan araştırmalarda belli bir olguya ilişkin, bireyin sahip olduğu algıların ortaya çıkarılması ve yorumlanması temel amaçtır (Yıldırım ve Şimşek, 2006, 72). 


\begin{tabular}{lcc} 
İlkokullar & Kiz & Erkek \\
\hline Köy İlkokulu (1) & 18 & 10 \\
Köy İlkokulu (2) & 22 & 25 \\
Sinop Merkez (1) & 58 & 39 \\
Sinop Merkez (2) & 55 & 32 \\
Toplam & 153 & 106 \\
\hline
\end{tabular}

\subsection{Verilerin Toplanması}

Araştırmanın başlangıcında, ilkokul dördüncü sınıf öğrencilerin metafor konusunda bilgi verilmiştir. Ardından öğrencilerden «Ceza ve Kural» kavramlarına ilişkin metafor oluşturmaları istenmiştir. İlkokul dördüncü sınıf öğrencilerinden «Ceza ve Kural» kavramlarına ilişkin algılarını ortaya çıkarmak için onlara "«Ceza» ............ gibidir; çünkü ......... ve "Kural .........gibidir; çünkü.............." biçiminde tümceler verilmiştir. Öğrencilerden bu tümceleri kendi algılama biçimlerine bağlı olarak tamamlamaları istenmiştir.

\subsection{Verilerin Analizi}

Verilerin analizinde nitel araştırma yöntemlerinden içerik analizi yöntemi (Yıldırım ve Şimşek, 2006) kullanılmıştır. Katılımcıların geliştirdikleri metaforlar beş aşamada analiz edilmiştir: (1) kodlama ve ayıklama aşaması, (2) örnek metafor imgesi derleme aşaması, (3) kategori geliştirme aşaması, (4) geçerlik ve güvenirliği sağlama aşaması ve (5) nicel veri analizi için verileri SPSS paket programına aktarma aşaması.

\subsection{Kodlama ve ayıklama aşaması}

$\mathrm{Bu}$ aşamada öncelikle katılımcılar tarafından üretilen metaforların alfabetik sıraya göre geçici bir listesi yapılmıştır. $\mathrm{Bu}$ amaç doğrultusunda katılımcıların yazılarında belli bir metaforu net bir şekilde dile getirip getirmediğine bakılmıştır. Bu aşamada basitçe her katılımcının sunduğu metafor kodlanmıştır (örneğin, "Müzik", "Okul”, vb.).

\section{6. Örnek metafor imgesi derleme aşaması}

Çalışmada yer alan 259 katılımcıdan toplam 223 adet geçerli metafor elde edilmiştir. $\mathrm{Bu}$ aşamada, bu metaforlar tekrar alfabetik sıraya göre dizilmiş ve ham veriler ikinci kez gözden geçirilmiştir.

Böylece, 223 metaforun her biri için onu en iyi temsil ettiği varsayılan katılımcı metafor imgelerinin derlenmesiyle birlikte bir "örnek metafor listesi" oluşturulmuştur. Bu liste, iki temel amaca yönelik olarak derlenmiştir: (a) metaforların belli bir kategori altında toplanmasında bir başvuru kaynağı olarak kullanmak ve (b) bu araştırmanın veri analiz sürecini ve yorumlarını geçerli kılmak. 


\subsection{Geçerlik ve güvenirlik}

Geçerlik ve güvenirlik, araştırma sonuçlarının inandırıcılığını sağlamak (veya artırmak) için kullanılan en önemli iki ölçüttür. "Toplanan verilerin ayrıntılı olarak rapor edilmesi ve araştırmacının sonuçlara nasıl ulaştığını açıklaması nitel bir araştırmada geçerliğin önemli ölçütleri arasında yer almaktadır" (Yıldırım ve Şimşek, 2006: 257).

Bu araştırmaya özgü olarak, araştırma sonuçlarının geçerliğini sağlamak amacıyla iki önemli işlem gerçekleştirilmiştir:

(1) Veri analiz süreci (özellikle de 4 kavramsal kategoriye nasıl ulaşıldığı) detaylı bir şekilde açıklanmıştır.

(2) Araştırmada elde edilen 4 metaforun her biri için onu en iyi temsil ettiği varsayılan bir örnek metafor imgesi derlenmiş ve bu metafor imgelerinin tümüne bulgular kısmında yer verilmiştir.

Araştırmanın güvenirliğini sağlamak için, araştırmada ulaşılan 4 kavramsal kategori altında verilen metafor imgelerinin söz konusu bir kavramsal kategoriyi temsil edip etmediğini teyit etmek amaciyla uzman görüşüne başvurulmuştur.

Karşılaştırmalarda "görüş birliği" ve "görüş ayrılı̆̆g” sayıları tespit edilerek araştırmanın güvenirliği Miles ve Huberman'ın (1994: 64) formülü (Güvenirlik = görüş birliği / görüş birliği + görüş ayrılığ X 100) kullanılarak hesaplanmıştır. Nitel çalışmalarda, uzman ve araştırmacı değerlendirmeleri arasındaki uyumun $\% 90$ ve üzeri olduğu durumlarda arzu edilen düzeyde bir güvenilirlik sağlanmış olmaktadır. Bu araştırmaya özgü olarak gerçekleştirilen güvenirlik çalışmasında $\% 97$ oranında bir uzlaşma (güvenirlik) sağlanmıştır.

\subsection{Kategori geliştirme aşaması}

$\mathrm{Bu}$ aşamada, temel olarak katılımcılar tarafindan üretilen metafor imgeleri ceza ve kural kavramına ilişkin sahip oldukları ortak özellikler bakımından irdelenmiştir. Bu işlem esnasında özellikle 223 metafor hakkında oluşturulan "örnek metafor listesi" baz alınarak her metafor imgesinin ceza ve kural algısının nasıl kavramsallaştırdığına bakılmıştır. Bu amaç için, katılımcılar tarafından üretilen her metafor imgesi:

(1) metaforun konusu,

(2) metaforun kaynağı ve

(3) metaforun konusu ile kaynağı arasındaki ilişki bakımlarından analiz edilmiştir.

Daha sonra her metafor imgesi ceza ve kural kavramlarına ilişkin sahip olduğu perspektif bakımından belli bir tema ile ilişkilendirilerek (örneğin, "Doğa kavramı olarak ceza ve kural ", vb.) toplam 4 farklı kavramsal kategori oluşturulmuştur. Oluşturulan bu kavramsal kategorilerde bulunan metaforlar doğuştan var olan temel duygular (Mutluluk, Korku, Kızgınlık ve Üzüntü) üzerinden üç başlık halinde ele alınmıştır. Yaşadığınız heyecan sizi eyleme hazırlayan durumum bireysel anlamının hızlı bir değerlendirilmesidir. Örneğin, mutluluk yaklaşmanıza, üzüntü edilgen bir biçimde geri çekilmenize ve kızgınlık engelleri aşmak için çalışmanıza yol açar (Berk, 2013, s:477). Bu çalışmada temel duygulardan yola çıkılarak metaforlar ifadeleri örneğin mutluluk; akıl, uyum, müzik, sorumluluk vb. korku; canavar, yaratık, emir, acı biber vb. kızgınlık ve üzüntü; yokluk, engellenme, yalnızlık, eziyet, yanlış vb.) şeklinde gruplandırılmıştır. 
3. Bulgular

3.1. Ceza Kavramı Algısına İlişkin Metafor Tabloları

3.2. Öğrencilerin ürettikleri ceza metaforlarına ait soyutluluk ifadelerinin dağılımları ne düzeydedir?

Tablo-2: Öğrencilerin Ceza Metaforlarına İlișkin Soyutluluk Iffadelerine Yönelik Frekans ve Yüzde Dağıllımları

\begin{tabular}{llcc} 
& & $\mathrm{n}$ & $\%$ \\
\hline & Koyutluluk & 36 & 16,0 \\
& Kizgınlık ve Üzüntü & 41 & 18,0 \\
& Mutluluk & 2 & 1,0 \\
\cline { 2 - 4 } & Toplam & 79 & 35,0 \\
\hline Diğer İfadeleri Seçenlerin Sayısı & 146 & 65,0 \\
Genel Toplam & 225 & 100,0 \\
\hline
\end{tabular}

Tablo 2'de öğrencilerin ceza metaforlarına ilişkin soyutluk ifadelerine yönelik frekans ve yüzde dağılımları incelendiğinde korku ifadesini 36 öğrenci (\%16), Kızgınlık ve üzüntü ifadesini 41 öğrenci $(\% 18)$ ve mutluluk ifadesini ise $2(\% 1)$ öğrencinin tercih ettiği görülmektedir. Ceza metaforuna ilişkin soyutluluk ifadelerinin alt temel duygu boyutuna bakıldığında öğrencilerin genel yaklaşımının olumsuz (Kızgınlık ve üzüntü, Korku) olduğu görülmektedir. Her bir temel duygu kategorisinden örnekler;

Mutluluk: Ceza önem'e benzer. Çünkü seni seven sana ceza verir. (Merkez (2) İlkokulu, Kız, Ö:193)

Kızgınlık ve Üzüntü: Ceza eziyete benzer. Çünkü ceza alınca mahrum kalıyoruz. (Merkez (1) İlkokulu, Erkek, Ö:66)

Korku: Ceza șeytana benzer. Çünkü şeytan bizi kötülüğe götürür. (Merkez (1) İlkokulu, Erkek, Ö:89)

\section{3. Öğrencilerin ürettikleri ceza metaforlarına ait yaşamsal ifadelerinin dağılımları ne düzeydedir?}

Tablo-3: Öğrencilerin Ceza Metaforlarına İlişkin Yaşamsal İfadelerine Yönelik Frekans ve Yüzde Dağllımları

\begin{tabular}{llcc} 
Yaşamsal & & $\mathrm{n}$ & $\%$ \\
\hline & Mutluluk & 43 & 19,1 \\
& Kızgınlık ve Üzüntü & 56 & 24,9 \\
& Korku & 39 & 17,3 \\
\cline { 2 - 4 } & Toplam & 138 & 61,3 \\
\hline Diğer İfadeleri Seçenlerin Sayısı & 87 & 38,7 \\
Genel Toplam & 225 & 100,0 \\
\hline
\end{tabular}


Tablo 3'de öğrencilerin ceza metaforlarına ilişkin yaşamsal ifadelerine yönelik frekans ve yüzde dağılımları incelendiğinde korku ifadesini 39 öğrenci $(\% 17,3)$, Kızgınlık ve üzüntü ifadesini 56 öğrenci $(\% 24,9)$ ve mutluluk ifadesini ise $43(\% 19,1)$ öğrencinin tercih ettiği görülmektedir. Ceza metaforuna ilişkin yaşamsal ifadelerinin alt temel duygu boyutuna bakıldığında öğrencilerin genel yaklaşımının dengeli (Kızgınlık ve üzüntü ve mutluluk) olduğu görülmektedir. Bu sonuçlardan hareketle yaşamsallığın içerisinde çocukların ceza kavramını çok fazla olumsuz algılamadığını söyleyebiliriz. Her bir temel duygu kategorisinden örnekler;

Mutluluk: Ceza trafik gibidir. Kırmızı yandığında durmak gerekir, iyi bilmiyorsan izleyip öğrenirsin. (Merkez (1) İlkokulu, Kız, Ö:54)

Kızgınlık ve Üzüntü: Ceza hapishaneye benzer. Çünkü karanlıktır. (Köy (2) İlkokulu, Kız, Ö:19)

Korku: Ceza ödül gibidir. Çünkü daha iyi oluruz.( Köy (1) İlkokulu, K1z, Ö:223)

3.3. Öğrencilerin ürettikleri ceza metaforlarına ait obje ifadelerinin dağılımları ne düzeydedir?

Tablo-4: Öğrencilerin Ceza Metaforlarına İlişkin Obje Iffadelerine Yönelik Frekans ve Yüzde Dağgllmları

\begin{tabular}{lcc}
\hline \multicolumn{1}{l}{ Obje } & $\mathrm{n}$ & $\%$ \\
\hline \multicolumn{1}{c}{ Mutluluk } & 4 & 1,8 \\
\hline Diğer İfadeleri Seçenlerin Sayısı & 221 & 98,2 \\
Genel Toplam & 225 & 100,0 \\
\hline
\end{tabular}

Tablo 4'de öğrencilerin ceza metaforlarına ilişkin obje ifadelerine yönelik frekans ve yüzde dağılımları incelendiğinde mutluluk ifadesine $4(\% 1,8)$ öğrencinin tercih ettiği görülmektedir. Ceza metaforuna ilişkin obje ifadelerinin alt temel duygu boyutuna bakıldığında öğrencilerin genel yaklaşımının olumlu (mutluluk) olduğu görülmektedir. Mutluluk temel duygu kategorisinden örnek;

Mutluluk: Ceza Balon'a benzer. Çünkü patlar.( Köy (2) İlkokulu, Kız, Ö:9)

\section{4. Öğrencilerin ürettikleri ceza metaforlarına ait Doğa ifadelerinin dağılımları ne düzeydedir?}

Tablo-5: Öğrencilerin Ceza Metaforlarına İlişkin Doğa Iffadelerine Yönelik Frekans ve Yüzde Dă̆ıllmları

\begin{tabular}{llcc} 
Doğa & $\mathrm{n}$ & $\%$ \\
\hline & Kızgınlık ve Üzüntü & 4 & 1,8 \\
& Korku & 1 &, 4 \\
\cline { 2 - 4 } & Toplam & 5 & 2,2 \\
\hline Diğer İfadeleri Seçenlerin Sayıs1 & 220 & 97,8 \\
Genel Toplam & 225 & 100,0 \\
\hline
\end{tabular}


Tablo 5'de öğrencilerin ceza metaforlarına ilişkin doğa ifadelerine yönelik frekans ve yüzde dağılımları incelendiğinde korku ifadesini 1 öğrenci $(\%, 4)$, Kızgınlık ve üzüntü ifadesini 4 öğrenci $(\% 1,8)$ öğrencinin tercih ettiği görülmektedir. Ceza metaforuna ilişkin doğa ifadelerinin alt temel duygu boyutuna bakıldığında öğrencilerin genel yaklaşımının olumsuz (Kızgınlık ve üzüntü, Korku) olduğu görülmektedir. Bu temel duygu kategorilerinden örnekler;

Kızgınlık ve Üzüntü: Ceza ağaca benzer. Çünkü yaprakları dökülür. (Köy (2) İlkokulu, Kiz, Ö:6)

Korku:Ceza acı bibere benzer. Acı verir. (Merkez (2), Kız, Ö:185)

\section{5. Öğrencilerin öğrenim gördükleri okulun türüne göre ürettikleri ceza metaforlarına ait soyutluluk ifadelerinin dağılımları ne düzeydedir?}

Tablo-6: Öğrencilerin Okul Türlerine Göre Ceza Metaforlarına İlişkin Soyutluluk İfadelerine Yönelik Frekans ve Yüzde Dă̆llımları

\begin{tabular}{|c|c|c|c|c|}
\hline \multirow[b]{2}{*}{ Soyutluluk } & \multirow[b]{2}{*}{ Dağılım } & \multicolumn{2}{|c|}{ Okul Türü } & \multirow{2}{*}{ Toplam } \\
\hline & & Şehir okulları & Köy okulları & \\
\hline \multirow[t]{2}{*}{ Mutluluk } & $\mathrm{n}$ & 2 & 0 & 2 \\
\hline & $\%$ & $100,0 \%$ &, $0 \%$ & $100,0 \%$ \\
\hline \multirow[t]{2}{*}{ Kızgınlık ve Üzüntü } & $\mathrm{n}$ & 40 & 1 & 41 \\
\hline & $\%$ & $97,6 \%$ & $2,4 \%$ & $100,0 \%$ \\
\hline \multirow[t]{2}{*}{ Korku } & $\mathrm{n}$ & 22 & 14 & 36 \\
\hline & $\%$ & $61,1 \%$ & $38,9 \%$ & $100,0 \%$ \\
\hline \multirow{2}{*}{ Toplam } & $\mathrm{n}$ & 64 & 15 & 79 \\
\hline & $\%$ & $100,0 \%$ & $100,0 \%$ & $100,0 \%$ \\
\hline
\end{tabular}

Tablo 6'da öğrencilerin okul türlerine göre ceza metaforlarına ilişkin soyutluluk ifadelerine yönelik frekans ve yüzde dağılımları incelediğinde şehir okullarında eğitim gören öğrencilerden 2'nin mutluluk ifadesine başvurduğu görülmektedir. Kızgınlık ve üzüntü ifadesini kullanan 40 öğrencinin $(\% 97,6)$ şehir okulunda, 1 öğrencinin $(\% 2,4)$ köy okulunda eğitim aldığı, Korku ifadesini kullanan 22 öğrencinin $(\% 61,1)$ şehir okulunda, 14 öğrencinin $(\% 38,9)$ köy okulunda eğitim aldıkları görülmektedir. 


\section{6. Öğrencilerin cinsiyetlerine göre ürettikleri ceza metaforlarına ait soyutluluk ifadelerinin dağılımları ne düzeydedir?}

Tablo-7: Öğrencilerin Cinsiyetlerine Göre Ceza Metaforlarına İlişkin Soyutluluk İfadelerine Yönelik Frekans ve Yüzde Dă̆ılımları

\begin{tabular}{lcccc}
\hline & & & Cinsiyet & \\
Soyutluluk & Dağılım & $\mathrm{K} 1 \mathrm{z}$ & Erkek & Toplam \\
\hline \multirow{2}{*}{ Mutluluk } & $\mathrm{n}$ & 2 & 0 & 2 \\
& $\%$ & $100,0 \%$ &, $0 \%$ & $100,0 \%$ \\
\multirow{2}{*}{ Kizgınlık ve Üzüntü } & $\mathrm{n}$ & 27 & 14 & 41 \\
& $\%$ & $65,9 \%$ & $34,1 \%$ & $100,0 \%$ \\
Korku & $\mathrm{n}$ & 22 & 14 & 36 \\
& $\%$ & $61,1 \%$ & $38,9 \%$ & $100,0 \%$ \\
\hline \multirow{2}{*}{ Toplam } & $\mathrm{n}$ & 51 & 28 & 79 \\
& $\%$ & $100,0 \%$ & $100,0 \%$ & $100,0 \%$ \\
\hline
\end{tabular}

Tablo 7'de öğrencilerin cinsiyetlerine göre ceza metaforlarına ilişkin soyutluluk ifadelerine yönelik frekans ve yüzde dağılımları incelediğinde kız öğrencilerden 2'nin mutluluk ifadesine başvurduğu görülmektedir. Kızgınlık ve üzüntü ifadesini kullanan 27 öğrencinin $(\% 65,9) \mathrm{kız}, 14$ öğrencinin $(\% 34,1)$ erkek, Korku ifadesini kullanan 22 öğrencinin $(\% 61,1)$ k1z, 14 öğrencinin $(\% 38,9)$ erkek öğrenci olduğu görülmektedir.

3.7. Öğrencilerin annelerinin mesleklerine göre ürettikleri ceza metaforlarına ait soyutluluk ifadelerinin dağılımları ne düzeydedir?

Tablo-8: Öğrencilerin Annelerinin Mesleklerine Göre Ceza Metaforlarına İlişkin Soyutluluk İfadelerine Yönelik Frekans ve Yüzde Dă̆llımları

\begin{tabular}{lccccc}
\hline & & & Anne Meslek & & Toplam \\
Soyutluluk & Dağılım & Ev Hanımı & Kamu Sektörü & Özel Sektör & 2 \\
\hline Mutluluk & $\mathrm{n}$ & 0 & 0 & 2 & $100,0 \%$ \\
& $\%$ &, $0 \%$ &, $0 \%$ & 12 & 41 \\
$\begin{array}{l}\text { Kızgınlık } \\
\text { Üzüntü }\end{array}$ & $\mathrm{n}$ & 19 & 10 & $29,3 \%$ & $100,0 \%$ \\
& $\%$ & $46,3 \%$ & $24,4 \%$ & 6 & 36 \\
Korku & $\mathrm{n}$ & 22 & 8 & $16,7 \%$ & $100,0 \%$ \\
\hline & $\mathrm{n}$ & $61,1 \%$ & $22,2 \%$ & 20 & 79 \\
Toplam & $\%$ & 41 & 18 & $100,0 \%$ & $100,0 \%$ \\
\hline
\end{tabular}

Tablo 8'de öğrencilerin annelerinin mesleklerine göre ceza metaforlarına ilişkin soyutluluk ifadelerine yönelik frekans ve yüzde dağılımları incelediğinde anneleri özel sektörde çalışan 
öğrencilerden 2'sinin mutluluk ifadesine başvurduğu görülmektedir. Kızgınlık ve üzüntü ifadesini kullanan 19 öğrencinin (\%46,3) annesi ev hanımı, 10 öğrencinin $(\% 24,4) a n n e s i$ kamuda, 12 öğrencinin (\%29,3)annesi ise özel sektörde çalı̧̧maktadır. Korku ifadesini kullanan 22 öğrencinin $(\% 61,1)$ annesi ev hanımı, 8 öğrencinin $(\% 22,2)$ annesi kamuda, 6 ögrencinin (\%16,7)annesi ise özel sektörde çalışmaktadır.

\section{8. Öğrencilerin babalarının mesleklerine göre ürettikleri ceza metaforlarına ait} soyutluluk ifadelerinin dağılımları ne düzeydedir?

Tablo-9: Öğrencilerin Babalarının Mesleklerine Göre Ceza Metaforlarına İlişkin Soyutluluk Ífadelerine Yönelik Frekans ve Yüzde Dağllımları

\begin{tabular}{|c|c|c|c|c|c|}
\hline Soyutluluk & Dağglım & Kamu & $\begin{array}{c}\text { Baba Meslek } \\
\text { Özel Sektör }\end{array}$ & Tarım & Toplam \\
\hline \multirow[t]{2}{*}{ Mutluluk } & $\mathrm{n}$ & 0 & 2 & 0 & 2 \\
\hline & $\%$ &, $0 \%$ & $100,0 \%$ &, $0 \%$ & $100,0 \%$ \\
\hline \multirow[t]{2}{*}{ Kızgınlık ve Üzüntü } & $\mathrm{n}$ & 15 & 24 & 2 & 41 \\
\hline & $\%$ & $36,6 \%$ & $58,5 \%$ & $4,9 \%$ & $100,0 \%$ \\
\hline \multirow[t]{2}{*}{ Korku } & $\mathrm{n}$ & 13 & 20 & 3 & 36 \\
\hline & $\%$ & $36,1 \%$ & $55,6 \%$ & $8,3 \%$ & $100,0 \%$ \\
\hline \multirow{2}{*}{ Toplam } & $\mathrm{n}$ & 28 & 46 & 5 & 79 \\
\hline & $\%$ & $100,0 \%$ & $100,0 \%$ & $100,0 \%$ & $100,0 \%$ \\
\hline
\end{tabular}

Tablo 9'da öğrencilerin babalarının mesleklerine göre ceza metaforlarına ilişkin soyutluluk ifadelerine yönelik frekans ve yüzde dağılımları incelediğinde babaları özel sektörde çalışan öğrencilerden 2'sinin mutluluk ifadesine başvurduğu görülmektedir. Kızgınlık ve üzüntü ifadesini kullanan 15 öğrencinin $(\% 36,6)$ babası kamu, 24 öğrencinin $(\% 58,5)$ babası özel sektör, 2 öğrencinin $(\% 4,9)$ babası ise tarımda çalışmaktadır. Korku ifadesini kullanan 3 öğrencinin $(\% 8,3)$ babası tarımda, 13 öğrencinin $(\% 36,1)$ babası kamuda, 20 öğrencinin $(\% 55,6)$ babası ise özel sektörde çalışmaktadır. 


\section{9. Öğrencilerin öğrenim gördükleri okulun türüne göre ürettikleri ceza metaforlarına ait yaşamsal ifadelerinin dağılımları ne düzeydedir?}

Tablo-10: Öğrencilerin Okul Türlerine Göre Ceza Metaforlarına İlişkin Yaşamsal İfadelerine Yönelik Frekans ve Yüzde Dă̆ılımları

\begin{tabular}{|c|c|c|c|c|c|}
\hline \multirow[b]{2}{*}{ Yaşamsal } & & \multirow[b]{2}{*}{ Dağılım } & \multicolumn{2}{|c|}{ Okul Türü } & \multirow{2}{*}{ Toplam } \\
\hline & & & Şehir okulları & Köy okulları & \\
\hline \multirow{2}{*}{ Mutluluk } & & $\mathrm{n}$ & 38 & 5 & 43 \\
\hline & & $\%$ & $88,4 \%$ & $11,6 \%$ & $100,0 \%$ \\
\hline \multirow{2}{*}{$\begin{array}{l}\text { K1zgınlık } \\
\text { Üzüntü }\end{array}$} & ve & $\mathrm{n}$ & 46 & 10 & 56 \\
\hline & & $\%$ & $82,1 \%$ & $17,9 \%$ & $100,0 \%$ \\
\hline \multirow{2}{*}{ Korku } & & $\mathrm{n}$ & 36 & 3 & 39 \\
\hline & & $\%$ & $92,3 \%$ & $7,7 \%$ & $100,0 \%$ \\
\hline \multirow{2}{*}{ Toplam } & & $\mathrm{n}$ & 120 & 18 & 138 \\
\hline & & $\%$ & $100,0 \%$ & $100,0 \%$ & $100,0 \%$ \\
\hline
\end{tabular}

$\mathrm{X}^{2}(2)=2,21, \mathrm{p}=, 332>05$

Tablo 10'da öğrencilerin okul türlerine göre ceza metaforlarına ilişkin yaşamsal ifadelerine yönelik frekans ve yüzde dağılımları incelediğinde şehir okullarında eğitim gören öğrencilerden 38'nin $(\% 88,4)$, köy okullarında eğitim gören öğrencilerden $5(\% 11,6)$ mutluluk ifadesine başvurduğu görülmektedir. Kızgınlık ve üzüntü ifadesini kullanan 46 öğrencinin $(\% 82,1)$ şehir okulunda, 10 öğrencinin $(\% 17,9))$ köy okulunda eğitim aldığ1, Korku ifadesini kullanan 36 öğrencinin $(\% 92,3)$ şehir okulunda, 3 öğrencinin $(\% 7,7)$ köy okulunda eğitim aldıkları görülmektedir. Bulgular incelendiğinde öğrencilerin ceza metaforlarına ilişkin yaşamsal ifadelerinin okul türlerine göre anlamlı farklılık göstermediği görülmektedir ( $\mathrm{p}>0,05)$.

3.10. Öğrencilerin cinsiyetlerine göre ürettikleri ceza metaforlarına ait yaşamsal ifadelerinin dağılımları ne düzeydedir?

Tablo-11: Öğrencilerin Cinsiyetlerine Göre Ceza Metaforlarına İlişkin Yaşamsal İfadelerine Yönelik Frekans ve Yüzde Dağllımlart

\begin{tabular}{|c|c|c|c|c|c|}
\hline \multirow[b]{2}{*}{ Yaşamsal } & & \multirow[b]{2}{*}{ Dağglım } & \multicolumn{2}{|c|}{ Cinsiyet } & \multirow{2}{*}{ Toplam } \\
\hline & & & $\mathrm{K} 1 \mathrm{z}$ & Erkek & \\
\hline \multirow{2}{*}{\multicolumn{2}{|c|}{ Mutluluk }} & $\mathrm{n}$ & 20 & 23 & 43 \\
\hline & & $\%$ & $46,5 \%$ & $53,5 \%$ & $100,0 \%$ \\
\hline \multirow{2}{*}{$\begin{array}{l}\text { Kızgınlık } \\
\text { Üzüntü }\end{array}$} & ve & $\mathrm{n}$ & 36 & 20 & 56 \\
\hline & & $\%$ & $64,3 \%$ & $35,7 \%$ & $100,0 \%$ \\
\hline \multirow{2}{*}{ Korku } & & $\mathrm{n}$ & 25 & 14 & 39 \\
\hline & & $\%$ & $64,1 \%$ & $35,9 \%$ & $100,0 \%$ \\
\hline \multirow{2}{*}{ Toplam } & & $\mathrm{n}$ & 81 & 57 & 138 \\
\hline & & $\%$ & $100,0 \%$ & $100,0 \%$ & $100,0 \%$ \\
\hline
\end{tabular}

$\mathrm{X}^{2}{ }_{(2)}=3,83, \mathrm{p}=, 148>0$ 
Tablo 11'de öğrencilerin cinsiyetlerine göre ceza metaforlarına ilişkin yaşamsal ifadelerine yönelik frekans ve yüzde dağılımları incelediğinde kız öğrencilerden 20'nin $(\% 46,5)$, erkek öğrencilerden $23(\% 53,5)$ mutluluk ifadesine başvurduğu görülmektedir. Kızgınlık ve üzüntü ifadesini kullanan 36 öğrencinin (\%64,3) kız, 20 öğrencinin $(\% 35,7)$ erkek, Korku ifadesini kullanan 25 öğrencinin $(\% 64,1)$ k1z, 14 öğrencinin $(\% 35,9)$ erkek olduğu görülmektedir. Bulgular incelendiğinde öğrencilerin ceza metaforlarına ilişkin yaşamsal ifadelerinin cinsiyetlere göre anlamlı farklılık göstermediği görülmektedir $(p>0,05)$.

3.11. Öğrencilerin annelerinin mesleklerine göre ürettikleri ceza metaforlarına ait yaşamsal ifadelerinin dağılımları ne düzeydedir?

Tablo-12: Öğrencilerin Annelerinin Mesleklerine Göre Ceza Metaforlarına İlişkin Yaşamsal İfadelerine Yönelik Frekans ve Yüzde Dağllımları

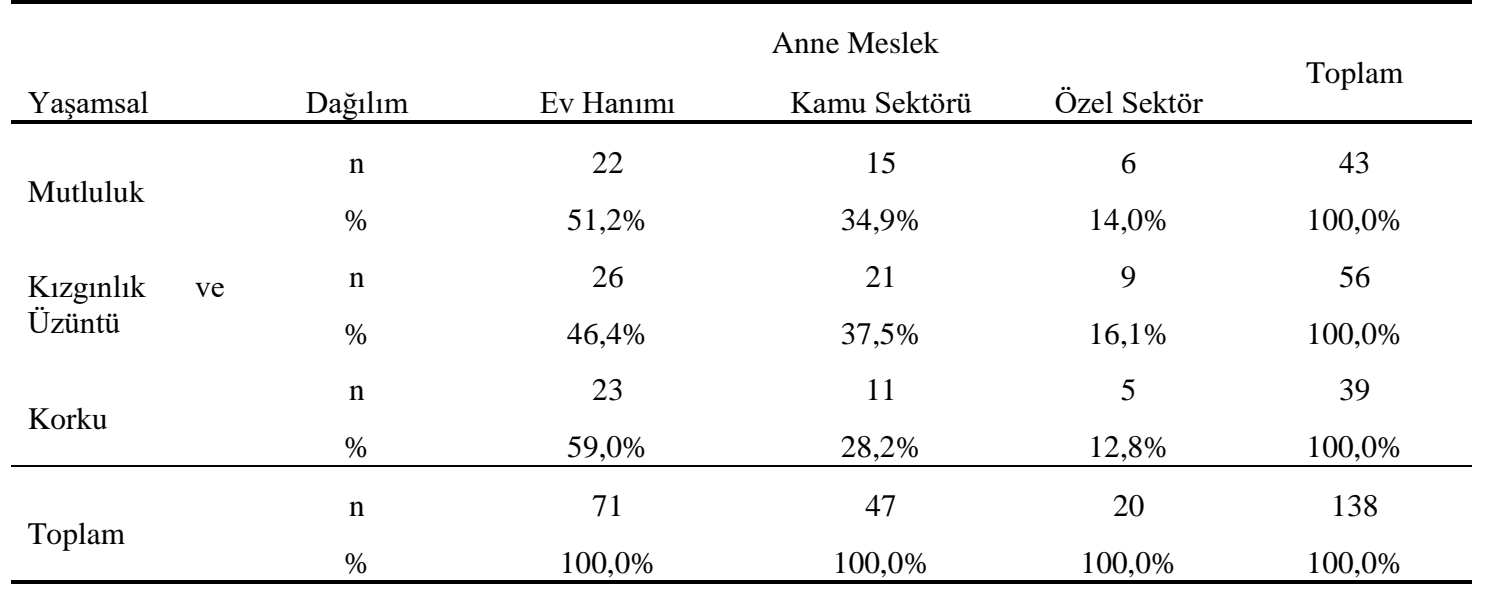

$\mathrm{X}_{(2)}^{2}=1,48, \mathrm{p}=, 830>05$

Tablo 12'de öğrencilerin annelerinin mesleklerine göre ceza metaforlarına ilişkin yaşamsal ifadelerine yönelik frekans ve yüzde dağılımları incelediğinde anneleri özel sektörde çalışan öğrencilerden 6'sinin (\%14), kamuda çalışanların 15'nin (\%34,9) ve ev hanımı olan 22'sinin $(\% 51,2)$ mutluluk ifadesine başvurduğu görülmektedir. Kızgınlık ve üzüntü ifadesini kullanan 26 öğrencinin $(\% 46,4)$ annesi ev hanımı, 21 öğrencinin $(\% 37,5)$ annesi kamuda, 9 öğrencinin $(\% 16,1)$ annesi ise özel sektörde çalışmaktadır. Korku ifadesini kullanan 23 öğrencinin (\%59) annesi ev hanımı, 11 öğrencinin (\%28,2)annesi kamuda, 5 öğrencinin $(\% 12,8)$ annesi ise özel sektörde çalışmaktadır. Bulgular incelendiğinde öğrencilerin ceza metaforlarına ilişkin yaşamsal ifadelerinin annelerinin mesleklerine göre anlamlı farklılık göstermediği görülmektedir ( $p>0,05)$. 


\subsection{2. Öğrencilerin sosyo-ekonomik statülerine göre ürettikleri ceza metaforlarına ait yaşamsal ifadelerinin dağılımları ne düzeydedir?}

Tablo-13: Öğrencilerin Sosyo-Ekonomik Statülerine Göre Ceza Metaforlarına İlişkin Yaşamsal İfadelerine Yönelik Frekans ve Yüzde Dağllımları

\begin{tabular}{|c|c|c|c|c|c|c|}
\hline \multirow[b]{2}{*}{ Yaşamsal } & & \multirow[b]{2}{*}{ Dağılım } & \multicolumn{3}{|c|}{ Sosyo-Ekonomik Statü } & \multirow{2}{*}{ Toplam } \\
\hline & & & Düşük & Orta & Yüksek & \\
\hline \multirow{2}{*}{ Mutluluk } & & $\mathrm{n}$ & 19 & 24 & 0 & 43 \\
\hline & & $\%$ & $44,2 \%$ & $55,8 \%$ &, $0 \%$ & $100,0 \%$ \\
\hline \multirow{2}{*}{$\begin{array}{l}\text { Kızgınlık } \\
\text { Üzüntü }\end{array}$} & ve & $\mathrm{n}$ & 20 & 35 & 1 & 56 \\
\hline & & $\%$ & $35,7 \%$ & $62,5 \%$ & $1,8 \%$ & $100,0 \%$ \\
\hline \multirow{2}{*}{ Korku } & & $\mathrm{n}$ & 22 & 16 & 1 & 39 \\
\hline & & $\%$ & $56,4 \%$ & $41,0 \%$ & $2,6 \%$ & $100,0 \%$ \\
\hline \multirow{2}{*}{ Toplam } & & $\mathrm{n}$ & 61 & 75 & 2 & 138 \\
\hline & & $\%$ & $100,0 \%$ & $100,0 \%$ & $100,0 \%$ & $100,0 \%$ \\
\hline
\end{tabular}

$\mathrm{X}_{(2)}^{2}=5,20, \mathrm{p}=, 267>05$

Tablo 13'de öğrencilerin babalarının mesleklerine göre ceza metaforlarına ilişkin yaşamsal ifadelerine incelediğinde orta sosyo-ekonomik statüde olan öğrencilerden 24'nun (\%55,8), sosyo-ekonomik statüsü düşük öğrencilerden ise 19'nun $(\% 44,2)$ mutluluk ifadesine başvurduğu görülmektedir. Kızgınlık ve üzüntü ifadesini kullanan 20 öğrencinin $(\% 35,7)$ sosyo-ekonomik statü düzeyi düşük, 35 öğrencinin $(\% 62,5)$ sosyo-ekonomik statüs düzeyi orta, bir öğrencinin $(\% 1,8)$ sosyo ekonomik statüsü ise yüksek düzeydedir. Korku ifadesini kullanan 22 öğrencinin $(\% 56,4)$ sosyo-ekonomik statüsü düşük, 16 öğrencinin $(\% 41)$ sosyoekonomik statüsü orta, bir öğrencinin $(\% 2,6)$ sosyo-ekonomik statüsü ise yüksek düzeydedir. Bulgular incelendiğinde öğrencilerin ceza metaforlarına ilişkin yaşamsal ifadelerinin sosyoekonomik statüye göre anlamlı farklılık göstermediği görülmektedir ( $>0,05)$.

4. Kural Kavramı Algısına İlişskin Metafor Tabloları

4. 1. Öğrencilerin ürettikleri kural metaforlarına ait soyutluluk ifadelerinin dağılımları ne düzeydedir?

\begin{tabular}{llcc} 
Soyutluluk & & $\mathrm{n}$ & $\%$ \\
\hline & Mutluluk & 39 & 17,1 \\
& Kizgınlık ve Üzüntü & 11 & 4,8 \\
& Korku & 4 & 1,8 \\
\cline { 2 - 4 } & Toplam & 54 & 23,7 \\
\hline Diğer İfadeleri Seçenlerin Sayısı & 174 & 76,3 \\
Genel Toplam & 228 & 100,0 \\
\hline
\end{tabular}


Tablo 14'de öğrencilerin kural metaforlarına ilişkin soyutluk ifadelerine yönelik frekans ve yüzde dağılımları incelendiğinde korku ifadesini 4 öğrenci $(\% 1,8)$, Kızgınlık ve üzüntü ifadesini 11 öğrenci (\%4.8) ve mutluluk ifadesini ise $39(\% 17,1)$ öğrencinin tercih ettiği görülmektedir. Kural metaforuna ilişkin soyutluk ifadelerinin alt temel duygu boyutuna bakıldığında öğrencilerin genel yaklaşımının olumlu (mutluluk)olduğu görülmektedir. Her bir temel duygu kategorisinden örnekler;

Mutluluk:_Kural müziğe benzer. Çünkü notaları vardır.(Sinop Merkez (1) İlkokulu, Erkek, Ö:1)

Kızgınlık ve Üzüntü: Kural kötüye benzer. Çünkü kuralları yapmazsak çok k1zarlar.(Sinop Merkez (2), İlkokulu, Erkek, Ö:139)

Korku: Korku_yaratığa benzer. Çünkü bizi sıkıştırır.( Sinop Merkez (2), İlkokulu, Erkek, Ö:169)

\section{2. Öğrencilerin ürettikleri kural metaforlarına ait yaşamsal ifadelerinin dağılımları ne düzeydedir?}

Tablo-15: Öğrencilerin Kural Metaforlarına İlişkin Yaşamsal Iffadelerine Yönelik Frekans ve Yüzde Dağllımları

\begin{tabular}{llcc} 
Yaşamsal & & $\mathrm{n}$ & $\%$ \\
\hline & Mutluluk & 153 & 67,1 \\
& Kızgınlık ve Üzüntü & 2 &, 9 \\
& Korku & 3 & 1,3 \\
\cline { 2 - 4 } & Toplam & 158 & 69,3 \\
\hline Diğer İfadeleri Seçenlerin Sayısı & 70 & 30,7 \\
Genel Toplam & 228 & 100,0 \\
\hline
\end{tabular}

Tablo 15'de öğrencilerin kural metaforlarına ilişkin yaşamsal ifadelerine yönelik frekans ve yüzde dağılımları incelendiğinde korku ifadesini 3 öğrenci (\% 1,3), Kızgınlık ve üzüntü ifadesini 2 öğrenci (\%9) ve mutluluk ifadesini ise 153 (\%67.1) öğrencinin tercih ettiğ görülmektedir. Kural metaforuna ilişkin yaşamsal ifadelerinin alt temel duygu boyutuna bakıldığında öğrencilerin genel yaklaşımının olumlu (mutluluk)olduğu görülmektedir. Her bir temel duygu kategorisinden örnekler;

Mutluluk:; Kural düzen gibidir. Çünkü temizliktir. (Köy (2) İlkokulu, Kız,Ö:6)

Kızgınlık ve Üzüntü:Kural engellenme gibidir. Çünkü bir saatten fazla tablet oynarsak beynimiz çürür.(Sinop Merkez (2) İlkokulu, Erkek, Ö:76)

Korku:Kural takip etmek gibidir. Çünkü peşimizdedir. (Sinop Merkez (2) İlkokulu, Erkek, Ö:137) 


\section{3. Öğrencilerin ürettikleri kural metaforlarına ait obje ifadelerinin dağılımları ne düzeydedir?}

Tablo-16: Öğrencilerin Kural Metaforlarına İlişkin Obje İfadelerine Yönelik Frekans ve Yüzde Dağılımları

\begin{tabular}{llcc} 
Obje & & $\mathrm{n}$ & $\%$ \\
\hline & Mutluluk & 8 & 3,5 \\
& Kızgınlık ve Üzüntü & 1 &, 4 \\
& Korku & 2 &, 9 \\
\cline { 2 - 4 } & Toplam & 11 & 4,8 \\
\hline Diğer İfadeleri Seçenlerin Sayısı & 217 & 95,2 \\
Genel Toplam & 228 & 100,0 \\
\hline
\end{tabular}

Tablo 16'da öğrencilerin kural metaforlarına ilişkin obje ifadelerine yönelik frekans ve yüzde dağılımları incelendiğinde korku ifadesini 2 öğrenci, Kızgınlık ve üzüntü ifadesini bir ögrenci ve mutluluk ifadesini ise $8(\% 3,5)$ öğrencinin tercih ettiği görülmektedir. Kural metaforuna ilişkin obje ifadelerinin alt temel duygu boyutuna bakıldığında öğrencilerin genel yaklaşımının olumlu (mutluluk)olduğu görülmektedir. Her bir temel duygu kategorisinden örnekler;

Mutluluk:Kural eve benzer. Çünkü kuralsız eşyaları kırabiliriz. (Sinop Merkez (1) İlkokulu, Erkek, Ö:75)

Kızgınlık ve Üzüntü: Kural çite benzer. Çünkü bahçeden kaçmamak içindir. (Sinop Merkez (1) İlkokulu, Erkek, Ö:59)

Korku: Kural bir değneğe benzer. Çünkü değnek kural demektir. (Sinop Merkez (1) K1z, Ö:90)

\section{4. Öğrencilerin ürettikleri Kural metaforlarına ait Doğa ifadelerinin dağılımları ne düzeydedir?}

Tablo-17: Öğrencilerin Kural Metaforlarına İlişkin Doğa Iffadelerine Yönelik Frekans ve Yüzde Dağılımları

\begin{tabular}{lcc} 
Doğa & $\mathrm{n}$ & $\%$ \\
\hline Kızgınlık ve Üzüntü & 2 &, 9 \\
\hline Diğer İfadeleri Seçenlerin Sayısı & 226 & 99,1 \\
Genel Toplam & 228 & 100,0 \\
\hline
\end{tabular}

Tablo 17'de öğrencilerin kural metaforlarına ilişkin doğa ifadelerine yönelik frekans ve yüzde dağılımları incelendiğinde kızgınlık ve üzüntü ifadesini iki öğrencinin tercih ettiği görülmektedir. Kuralmetaforunailişkin doğa ifadelerinin alt temel duygu boyutuna bakıldığında öğrencilerin sadece kızgınlık ve üzüntü boyutunda ifadeleri bulunmaktadır. Bu kategoriden bir örnek; 
Kelebek; Kural kelebeğe benzer. Çünkü kısa yaşar. (Sinop Merkez (2) İlkokulu, Kız, Ö:153)

4.5. Öğrencilerin öğrenim gördükleri okulun türüne göre ürettikleri kural metaforlarına ait soyutluluk ifadelerinin dağılımları ne düzeydedir?

Tablo-18: Öğrencilerin Okul Türlerine Göre Kural Metaforlarına İlişkin Soyutluluk İfadelerine Yönelik Frekans ve Yüzde Dağgllımları

\begin{tabular}{|c|c|c|c|c|c|}
\hline \multirow[b]{2}{*}{ Soyutluluk } & & \multirow[b]{2}{*}{ Dağglım } & \multicolumn{2}{|c|}{ Okul Türü } & \multirow{2}{*}{ Toplam } \\
\hline & & & Şehir okulları & Köy okulları & \\
\hline \multirow{2}{*}{ Mutluluk } & & $\mathrm{n}$ & 32 & 7 & 39 \\
\hline & & $\%$ & $74,4 \%$ & $63,6 \%$ & $72,2 \%$ \\
\hline \multirow{2}{*}{$\begin{array}{l}\text { Kizgınlık } \\
\text { Üzüntü }\end{array}$} & ve & $\mathrm{n}$ & 9 & 2 & 11 \\
\hline & & $\%$ & $20,9 \%$ & $18,2 \%$ & $20,4 \%$ \\
\hline \multirow{2}{*}{ Korku } & & $\mathrm{n}$ & 2 & 2 & 4 \\
\hline & & $\%$ & $4,7 \%$ & $18,2 \%$ & $7,4 \%$ \\
\hline \multirow{2}{*}{ Toplam } & & $\mathrm{n}$ & 43 & 11 & 54 \\
\hline & & $\%$ & $100,0 \%$ & $100,0 \%$ & $100,0 \%$ \\
\hline
\end{tabular}

Tablo 18'de öğrencilerin okul türlerine göre kural metaforlarına ilişkin soyutluluk ifadelerine yönelik frekans ve yüzde dağılımları incelediğinde şehir okullarında eğitim gören öğrencilerden 32'nin $(\% 74,4)$, köy okulunda eğitim gören öğrencilerden $7(\% 63,6)$ mutluluk

ifadesine başvurduğu görülmektedir. Kızgınlık ve üzüntü ifadesini kullanan 9 öğrencinin $(\% 20,9)$ şehir okulunda, iki öğrencinin $(\% 18,2)$ köy okulunda eğitim aldığ1, korku ifadesini kullanan 2 öğrencinin $(\% 4,7)$ şehir okulunda, 2 öğrencinin $(\% 18,2)$ köy okulunda eğitim aldıkları görülmektedir.

4.6. Öğrencilerin cinsiyetlerine göre ürettikleri kural metaforlarma ait soyutluluk ifadelerinin dağılımları ne düzeydedir?

Tablo-19: Öğrencilerin Cinsiyetlerine Göre Kural Metaforlarına İlişkin Soyutluluk Ifadelerine Yönelik Frekans ve Yüzde Dă̆ılımları

\begin{tabular}{lcccc}
\hline & & \multicolumn{2}{c}{ Cinsiyet } & Toplam \\
Soyutluluk & Dağılım & $\mathrm{K} 1 \mathrm{z}$ & Erkek & 39 \\
\hline \multirow{2}{*}{ Mutluluk } & $\mathrm{n}$ & 23 & 16 & $72,2 \%$ \\
Kizgınlık ve & $\%$ & $71,9 \%$ & $72,7 \%$ & 11 \\
Üzüntü & $\mathrm{n}$ & 9 & 2 & $20,4 \%$ \\
Korku & $\%$ & $28,1 \%$ & $9,1 \%$ & 4 \\
& $\mathrm{n}$ & 0 & 4 & $7,4 \%$ \\
Toplam & $\%$ &, $0 \%$ & 22 & 54 \\
& $\mathrm{n}$ & 32 & $100,0 \%$ & $100,0 \%$ \\
\hline
\end{tabular}


Tablo 19'da öğrencilerin cinsiyetlerine göre kural metaforlarına ilişkin soyutluluk ifadelerine yönelik frekans ve yüzde dağılımları incelediğinde kız öğrencilerden 23'nün $(\% 71,9)$, erkek öğrencilerin ise 16'in (\%72,7) mutluluk ifadesine başvurduğu görülmektedir. Kızgınlık ve üzüntü ifadesini kullanan 9 öğrencinin $(\% 28,1)$ kız, 2 öğrencinin $(\% 9,1)$ erkek olduğu görülmektedir. Korku ifadesini kullanan 4 öğrencinin $(\% 18,2)$ erkek öğrenci olduğu görülmektedir.

\section{7. Öğrencilerin anne mesleklerine göre ürettikleri kural metaforlarına ait soyutluluk ifadelerinin dağılımları ne düzeydedir?}

Tablo-20: Öğrencilerin Anne Mesleklerine Göre Kural Metaforlarına İlişkin Soyutluluk İfadelerine Yönelik Frekans ve Yüzde Dağllımları

\begin{tabular}{|c|c|c|c|c|c|c|}
\hline Soyutluluk & & Dağılım & Ev Hanımı & $\begin{array}{r}\text { Anne Meslek } \\
\text { Kamu Sektörü }\end{array}$ & Özel Sektör & Toplam \\
\hline \multirow{2}{*}{ Mutluluk } & & $\mathrm{n}$ & 21 & 9 & 9 & 39 \\
\hline & & $\%$ & $75,0 \%$ & $69,2 \%$ & $69,2 \%$ & $72,2 \%$ \\
\hline \multirow{2}{*}{$\begin{array}{l}\text { Kizgınlık } \\
\text { Üzüntü }\end{array}$} & ve & $\mathrm{n}$ & 5 & 3 & 3 & 11 \\
\hline & & $\%$ & $17,9 \%$ & $23,1 \%$ & $23,1 \%$ & $20,4 \%$ \\
\hline \multirow{2}{*}{ Korku } & & $\mathrm{n}$ & 2 & 1 & 1 & 4 \\
\hline & & $\%$ & $7,1 \%$ & $7,7 \%$ & $7,7 \%$ & $7,4 \%$ \\
\hline \multirow{2}{*}{ Toplam } & & $\mathrm{n}$ & 28 & 13 & 13 & 54 \\
\hline & & $\%$ & $100,0 \%$ & $100,0 \%$ & $100,0 \%$ & $100,0 \%$ \\
\hline
\end{tabular}

Tablo 20'de öğrencilerin annelerinin mesleklerine göre kural metaforlarına ilișkin soyutluluk ifadelerine yönelik frekans ve yüzde dağılımları incelediğinde anneleri özel sektörde çalışan öğrencilerden 9'nun $(69,2 \%)$ mutluluk ifadesine, 3'nün $(\% 23,1)$ kızgınlık ve üzüntü ifadesine ve bir öğrencinin korku ifadesine başvurduğu görülmektedir. Anneleri ev hanımı olan öğrencilerin 21 'nin $(\% 75)$ mutluluk ifadesine, 5'nin (\%17,9) kızgınlık ve üzüntü ifadesine ve 2'nin $(\% 7,1)$ korku ifadesine başvurduğu görülmektedir. Annesi kamu sektöründe çalışan öğrencilerden 9'nun $(\% 69,2)$ mutluluk ifadesine, 3 'nün $(\% 23,1)$ kızgınlık ve üzüntü ifadesine ve bir ögrencinin ise korku ifadesine başvurduğu görülmektedir. 


\section{8. Öğrencilerin baba mesleklerine göre ürettikleri kural metaforlarına ait soyutluluk ifadelerinin dağılımları ne düzeydedir?}

Tablo-21: Öğrencilerin Baba Mesleklerine Göre Kural Metaforlarına İlişkin Soyutluluk İfadelerine Yönelik Frekans ve Yüzde Dă̆llımlart

\begin{tabular}{|c|c|c|c|c|c|c|}
\hline Soyutluluk & & Dağglım & Kamu & $\begin{array}{l}\text { Baba Meslek } \\
\text { Özel Sektör }\end{array}$ & Tarım & Toplam \\
\hline \multirow{2}{*}{ Mutluluk } & & $\mathrm{n}$ & 13 & 24 & 2 & 39 \\
\hline & & $\%$ & $61,9 \%$ & $80,0 \%$ & $66,7 \%$ & $72,2 \%$ \\
\hline \multirow{2}{*}{$\begin{array}{l}\text { K1zgınlık } \\
\text { Üzüntü }\end{array}$} & ve & $\mathrm{n}$ & 6 & 5 & 0 & 11 \\
\hline & & $\%$ & $28,6 \%$ & $16,7 \%$ &, $0 \%$ & $20,4 \%$ \\
\hline \multirow{2}{*}{ Korku } & & $\mathrm{n}$ & 2 & 1 & 1 & 4 \\
\hline & & $\%$ & $9,5 \%$ & $3,3 \%$ & $33,3 \%$ & $7,4 \%$ \\
\hline \multirow{2}{*}{ Toplam } & & $\mathrm{n}$ & 21 & 30 & 3 & 54 \\
\hline & & $\%$ & $100,0 \%$ & $100,0 \%$ & $100,0 \%$ & $100,0 \%$ \\
\hline
\end{tabular}

Tablo 21'de öğrencilerin babalarının mesleklerine göre kural metaforlarına ilişkin soyutluluk ifadelerine yönelik frekans ve yüzde dağılımları incelediğinde babaları özel sektörde çalışan öğrencilerden 24'nün (\%80) mutluluk ifadesine, 5'nin (\%16,7) kızgınlık ve üzüntü ifadesine ve bir öğrencinin korku ifadesine başvurduğu görülmektedir. Babaları tarımda çalışan öğrencilerin 2'nin $(\% 66,7)$ mutluluk ifadesine, bir öğrencinin korku ifadesine başvurduğu görülmektedir. Babası kamu sektöründe çalışan öğrencilerden 13'nün $(\% 61,9)$ mutluluk ifadesine, 6'ın $(\% 28,6)$ kızgınlık ve üzüntü ifadesine ve 2 öğrencinin ise korku ifadesine başvurduğu görülmektedir.

\section{9. Öğrencilerin öğrenim gördükleri okulun türüne göre ürettikleri kuralmetaforlarına ait yaşamsal ifadelerinin dağılımları ne düzeydedir?}

Tablo-22: Öğrencilerin Okul Türlerine Göre Kural Metaforlarına İlişkin Yaşamsal İfadelerine Yönelik Frekans ve Yüzde Dă̆llımları

\begin{tabular}{|c|c|c|c|c|c|}
\hline \multirow[b]{2}{*}{ Yaşamsal } & & \multirow[b]{2}{*}{ Dağılım } & \multicolumn{2}{|c|}{ Okul Türü } & \multirow{2}{*}{ Toplam } \\
\hline & & & Şehir okulları & Köy okulları & \\
\hline \multirow[t]{2}{*}{ Mutluluk } & & $\mathrm{n}$ & 126 & 27 & 153 \\
\hline & & $\%$ & $96,9 \%$ & $96,4 \%$ & $96,8 \%$ \\
\hline \multirow{2}{*}{$\begin{array}{l}\text { Kizgınlık } \\
\text { Üzüntü }\end{array}$} & ve & $\mathrm{n}$ & 2 & 0 & 2 \\
\hline & & $\%$ & $1,5 \%$ &, $0 \%$ & $1,3 \%$ \\
\hline \multirow[t]{2}{*}{ Korku } & & $\mathrm{n}$ & 2 & 1 & 3 \\
\hline & & $\%$ & $1,5 \%$ & $3,6 \%$ & $1,9 \%$ \\
\hline \multirow{2}{*}{ Toplam } & & $\mathrm{n}$ & 130 & 28 & 158 \\
\hline & & $\%$ & $100,0 \%$ & $100,0 \%$ & $100,0 \%$ \\
\hline
\end{tabular}


Tablo 22'de öğrencilerin okul türlerine göre kural metaforlarına ilişkin yaşamsal ifadelerine yönelik frekans ve yüzde dağılımları incelediğinde şehir okullarında eğitim gören öğrencilerden 126'sının (\%96,9), köy okullarında eğitim gören öğrencilerden $27(\% 96,4)$ mutluluk ifadesine başvurduğu görülmektedir. Kızgınlık ve üzüntü ifadesini kullanan 2 öğrencinin $(\% 1,5)$ şehir okullarında eğitim aldığı görülmektedir. Korku ifadesini kullanan 2 öğrencinin $(\% 1,5)$ şehir okulunda, bir öğrencinin köy okulunda eğitim aldıkları görülmektedir.

\subsection{0. Öğrencilerin cinsiyetlerine göre ürettikleri kural metaforlarına ait yaşamsal ifadelerinin dağılımları ne düzeydedir?}

Tablo-23: Öğrencilerin Cinsiyetlerine Göre Kural Metaforlarına İlişkin Yaşamsal İfadelerine Yönelik Frekans ve Yüzde Dă̆llımlart

\begin{tabular}{|c|c|c|c|c|c|}
\hline \multirow[b]{2}{*}{ Yaşamsal } & & \multirow[b]{2}{*}{ Dağılım } & \multicolumn{2}{|c|}{ Cinsiyet } & \multirow{2}{*}{ Toplam } \\
\hline & & & $\mathrm{K} 1 \mathrm{Z}$ & Erkek & \\
\hline \multirow{2}{*}{ Mutluluk } & & $\mathrm{n}$ & 97 & 56 & 153 \\
\hline & & $\%$ & $98,0 \%$ & $94,9 \%$ & $96,8 \%$ \\
\hline \multirow{2}{*}{$\begin{array}{l}\text { K1zgınlık } \\
\text { Üzüntü }\end{array}$} & ve & $\mathrm{n}$ & 1 & 1 & 2 \\
\hline & & $\%$ & $1,0 \%$ & $1,7 \%$ & $1,3 \%$ \\
\hline \multirow{2}{*}{ Korku } & & $\mathrm{n}$ & 1 & 2 & 3 \\
\hline & & $\%$ & $1,0 \%$ & $3,4 \%$ & $1,9 \%$ \\
\hline \multirow{2}{*}{ Toplam } & & $\mathrm{n}$ & 99 & 59 & 158 \\
\hline & & $\%$ & $100,0 \%$ & $100,0 \%$ & $100,0 \%$ \\
\hline
\end{tabular}

Tablo 23'de öğrencilerin cinsiyetlerine göre kural metaforlarına ilişkin yaşamsal ifadelerine yönelik frekans ve yüzde dağılımları incelediğinde kız öğrencilerden 97'nin (\%98), erkek öğrencilerden $56(\% 94,9)$ mutluluk ifadesine başvurduğu görülmektedir. Kızgınlık ve üzüntü ifadesini kullanan bir öğrencinin kız, bir öğrencinin erkek, korku ifadesini kullanan bir öğrencinin kız, 2 öğrencinin erkek olduğu görülmektedir. 


\subsection{1. Öğrencilerin annelerinin mesleklerine göre ürettikleri kural metaforlarına ait yaşamsal ifadelerinin dağılımları ne düzeydedir?}

Tablo-24: Öğrencilerin Annelerinin Mesleklerine Göre Kural Metaforlarına İlişkin Yaşamsal İfadelerine Yönelik Frekans ve Yüzde Dă̆llımlart

\begin{tabular}{|c|c|c|c|c|c|}
\hline \multirow[b]{2}{*}{ Yaşamsal } & \multicolumn{4}{|c|}{ Anne Meslek } & \multirow[b]{2}{*}{ Toplam } \\
\hline & Dağılım & Ev Hanımı & $\begin{array}{c}\text { Kamu } \\
\text { Sektörü }\end{array}$ & Özel Sektör & \\
\hline \multirow{2}{*}{ Mutluluk } & $\mathrm{n}$ & 83 & 47 & 23 & 153 \\
\hline & $\%$ & $98,8 \%$ & $97,9 \%$ & $88,5 \%$ & $96,8 \%$ \\
\hline \multirow{2}{*}{ Kızgınlık ve üzüntü } & $\mathrm{n}$ & 0 & 1 & 1 & 2 \\
\hline & $\%$ &, $0 \%$ & $2,1 \%$ & $3,8 \%$ & $1,3 \%$ \\
\hline \multirow{2}{*}{ Korku } & $\mathrm{n}$ & 1 & 0 & 2 & 3 \\
\hline & $\%$ & $1,2 \%$ &, $0 \%$ & $7,7 \%$ & $1,9 \%$ \\
\hline \multirow{2}{*}{ Toplam } & $\mathrm{n}$ & 84 & 48 & 26 & 158 \\
\hline & $\%$ & $100,0 \%$ & $100,0 \%$ & $100,0 \%$ & $100,0 \%$ \\
\hline
\end{tabular}

Tablo 24'de öğrencilerin annelerinin mesleklerine göre kural metaforlarına ilişkin yaşamsal ifadelerine yönelik frekans ve yüzde dağılımları incelediğinde anneleri özel sektörde çalışan öğrencilerden 23'nün $(\% 88,5)$, kamuda çalışanların 47'nin $(\% 97,9)$ ve ev hanımı olan 83'ün $(\% 98,8)$ mutluluk ifadesine başvurduğu görülmektedir. Kızgınlık ve üzüntü ifadesini kullanan 1 öğrencinin annesi kamuda, bir öğrencinin annesi ise özel sektörde çalışmaktadır. Korku ifadesini kullanan bir öğrencinin annesi ev hanımı ve 2 öğrencinin annesi ise özel sektörde çalışmaktadır.

4.12. Öğrencilerin sosyo-ekonomik statülerine göre ürettikleri kural metaforlarına ait yaşamsal ifadelerinin dağılımları ne düzeydedir?

Tablo-25: Öğrencilerin Sosyo-Ekonomik Statülerine Göre Kural Metaforlarına İlişkin Yaşamsal Ífadelerine Yönelik Frekans ve Yüzde Dă̆llımları

\begin{tabular}{|c|c|c|c|c|c|c|}
\hline \multirow[b]{2}{*}{ Yaşamsal } & & \multirow[b]{2}{*}{ Dağılım } & \multicolumn{3}{|c|}{ Sosyo-Ekonomik Statü } & \multirow{2}{*}{ Toplam } \\
\hline & & & Düşük & Orta & Yüksek & \\
\hline \multirow{2}{*}{ Mutluluk } & \multirow{6}{*}{ ve } & $\mathrm{n}$ & 63 & 83 & 7 & 153 \\
\hline & & $\%$ & $95,5 \%$ & $97,6 \%$ & $100,0 \%$ & $96,8 \%$ \\
\hline \multirow{2}{*}{$\begin{array}{l}\text { Kizgınlık } \\
\text { Üzüntü }\end{array}$} & & $\mathrm{n}$ & 2 & 0 & 0 & 2 \\
\hline & & $\%$ & $3,0 \%$ &, $0 \%$ &, $0 \%$ & $1,3 \%$ \\
\hline \multirow{2}{*}{ Korku } & & $\mathrm{n}$ & 1 & 2 & 0 & 3 \\
\hline & & $\%$ & $1,5 \%$ & $2,4 \%$ &, $0 \%$ & $1,9 \%$ \\
\hline \multirow{2}{*}{ Toplam } & & $\mathrm{n}$ & 66 & 85 & 7 & 158 \\
\hline & & $\%$ & $100,0 \%$ & $100,0 \%$ & $100,0 \%$ & $100,0 \%$ \\
\hline
\end{tabular}


Tablo 25'de öğrencilerin sosyo-ekonomik statülerine göre kural metaforlarına ilişkin yaşamsal ifadelerine incelediğinde sosyo-ekonomik statüsü orta olan öğrencilerden 83'nun $(\% 97,6)$, sosyo-ekonomik statüsü düşük olan öğrencilerden 63'ünün $(\% 95,5)$ ve sosyoekonomik statüsü yüksek 7 öğrencinin mutluluk ifadesine başvurduğu görülmektedir. Kızgınlık ve üzüntü ifadesini kullanan 2 öğrencinin sosyo-ekonomik düzeyi düşüktür. Korku ifadesini kullanan bir öğrencinin babası kamuda, 2 öğrencinin babası özel sektörde çalışmaktadır.

\section{Tartıșma, Sonuç ve Öneriler}

Bu çalışmanın amacı, İlkokul dördüncü sınıf öğrencilerinin «Ceza ve Kural» kavramlarına İlişkin oluşturdukları metaforları toplamak ve toplanan bu metaforları çeşitli kategoriler altında sınıflandırarak İlkokul 4.sınıf öğrencilerinin algılama biçimlerini ortaya koymak amacıyla gerçekleştirilmiştir. Ceza ve Kural kavramları oluşumları, uygulanmaları, çeşitlilikleri, karmaşık olguları, sınırlarının belirlenememesi, insan eğitimi, düzeni, yaşamsallığı için önemi, işlevleri ve değişkenlikleri nedeniyle oldukça karmaşık kavramlardır. Bundan ötürü bir veya birkaç metafor ile algılanmaları ve açıklanmaları güçtür. Çalışmamızda farklı değişkenler kullanılarak ceza ve kural kavramlarının ilkokul dördüncü sınıf öğrencileri tarafından nasıl algılandığının belirlenmesi amacıyla 12'er alt soru belirlenmiştir. $\mathrm{Bu}$ sorulardan elde edilen bulgular incelendiğinde, ceza metaforuna yükledikleri anlama ilişkin öğrencilerin algılarına bakıldığında, soyutluluk ifadesi olarak şehir okullarında kızgınlık ve üzüntü/ korku temel duygularının köy okullarında okuyan öğrencilere göre daha yüksek olduğu tespit edilmiştir. Bu sonuç şehir okullarında öğrenci sayısının çok oluşu nedeni ile disiplin sağlanması amacıyla ceza türlerine muhtemelen daha çok başvurulmasından kaynaklı olabilir. Uysal vd. (2009) yaptıkları bir araştırmada öğretmenlerin istenmedik davranışlarda uyarı ve cezayı ilk strateji olarak kullandıkları bulgusuna ulaşmışlardır. Ayrıca öğretmenlerin istenmedik davranışları düzeltme yöntemleri düşünüldüğünde ise tepkisel modeli uyguladıklarını gözlemlemişlerdir. Tepkisel model müdahalenin işlevselliği konusunda Yaman ve Güven (2014)'in yaptıkları bir çalışmada öğrencilerin kendilerine verilen ceza hakkında genel olarak olumsuz yargilara sahip olduklarını, derse ve öğretmene karşı bir önyargı oluşturabildiklerini tespit etmişlerdir. Ayrıca Tüzel ve Şahin, 2014'teki bir araştırmalarında birinci kademe öğrencilerine okul yöneticilerine karşı tutumlarını belirlemek amacıyla resimler çizdirmişlerdir. Öğrencilerin çizdikleri resimlerin dörtte üçü okul yöneticileri hakkında olumlu durumları tasvir etmiştir. Olumsuz resimleme yapan öğrencilerin ise "dayak, ceza, şiddet ve azarlama" durumlarını resimlerine yansıttıkları görülmüștür (Forceville, 2002). Bu çalışmalar ile benzer bulgulara Yalçın ve Erginer, 2012'deki "İlköğretim Okullarında Okul Müdürüne İlişkin Metaforik Algılar" isimli çalışmalarında öğretmen, öğrenci ve veli görüşlerini almışlardır. Öğrenciler "sinir küpü”, öğretmenler "padişah" ve "diktatör", veliler "padişah", "para makinesi”, "Napolyon" metaforlarını en fazla üretmişlerdir. Ateş (2016) araştırmasında öğretmen kavramı ile ilişkili olarak sevilmeyen ve cezalandırıcı, sıkıcı ve yorucu, değişken ve beklenmedik biri; okul ile ilişkili olarak ise sevilmeyen ve ceza yeri olarak okul şeklindeki olumsuz algıları en çok 8. sınıf öğrencilerinde tespit etmiştir.

Ceza metaforuna yükledikleri anlama ilişkin öğrencilerin algılarına bakıldığında, soyutluluk ifadesi olarak cinsiyet değişkeni açısından kızgınlık ve üzüntü/korku temel duygularında kız öğrencilerin sayısı erkek ögrencilerden fazla olduğu görülmüştür. $\mathrm{Bu}$ tespitin temelinde kültürel çocuk eğitim yaklaşımlarının etkisi olabilir. Nitekim (Bilir, vd.,1991) metaforlardaki geleneksel dokuya da baktıkları bir çalışmada "Erkek adam ağlamaz, erkek adam korkmaz" deyişleri toplumun algılamalarını ortaya çıkarmaktadır. Bu algılamaların içselleştirilmesi 
içinde büyüyen kız ve erkek çocukları için "korkmak" sadece kız çocuğunu tanımlayan bir özellik olarak yaşamsallaşmıştır.

Öğrencilerin annelerinin mesleklerine göre ürettikleri ceza metaforlarına ait soyutluluk ifadelerinin dağılımlarına bakıldığında kızgınlık ve üzüntü/korku temel duygu içeren gruplarda ev hanımlarının çocuklarının, kamu ve özel sektörde çalışan annelerin çocuklarından daha çok metafor ürettikleri görülmüştür. Bu bulguya dayanarak ev hanımı olan annelerin çocuklarına kızgınlı/üzüntü/korku duygularına yol açan cezaları kamu ve özel sektördeki annelerden daha fazla verdiklerini belirtebiliriz. Bu bulguya paralel olarak (Bilir, Arı, Dönmez, Atik ve San, 1991) çocuklarına fiziksel ceza uygulayan annelerin çalışma durumlarıyla çocuklarını cezalandırmaları arasındaki ilişki incelendiklerinde bulguların istatistiksel analizi önemlilik göstermiştir. Araştırmanın sonucuna göre ev hanımı anneler (\%65.9) çalışan annelere (\%45.8) oranla çocuklarına daha fazla fiziksel ceza uygulamaktadir.

Öğrencilerin babalarının mesleklerine göre ürettikleri ceza metaforlarına ait soyutluluk ifadelerinin dağılımlarına bakıldığında kızgınlık ve üzüntü/korku temel duygu içeren gruplarda özel sektörde çalışan babaların çocuklarının, kamu ve tarımda çalışan babaların çocuklarından daha fazla metafor ürettikleri bulunmuştur. Özel sektördeki iş yükü ve mesai saatlerinin çok uzun olmasını göz önünde bulundurulursa, eve geldiklerinde veya gün içerisinde babaların stresli olmaları olasıdır. Bu stres dayanıklılık eşiğini azaltacağından özel sektördeki babaların çocuklarına neden kızgınlık/üzüntü/korku duygularına yol açan cezaları kamu ve tarımdaki babalardan daha fazla verdiklerini anlayabiliriz.

Öğrencilerin öğrenim gördükleri okulun türüne göre ürettikleri kural metaforlarına ait soyutluluk ifadelerinin dağılımlarına bakıldığında mutluluk temel duygusunun şehir okullarında köy okullarına göre yüzdesinin fazla olduğu görülmektedir. Bu bulgu şehir okullarındaki disiplin uygulamalarında kullanılan kurallara öğrencilerin yaklaşımının olumlu olduğunu düşündürmektedir. Bulunan sonuç ile aynı doğrultuda (Karabay ve Asi, 2015) yaptıkları bir çalışmada çocuklara "Kurallar sence neden gerekli?" sorusu soruluyor. Çocukların en çok anlamlandırılmış gerekliliklerinden "zarar vermemek için" cevabını vermiş olmaları kuralları istendik yönde benimsedikleri düşündürmektedir. Boyacı (2009) tarafından yapılan bir araştırmada, öğrencilere sınıf kuralları sorulduğunda; ögrrencilerin koşmamak, söz alarak konuşmak gibi davranışa yönelik, ardından çevreyi, okulu, sinıfi temiz tutmak gibi temizlik ve düzene yönelik, son olarak da eşyalara zarar vermemek gibi zarar vermeme amaçlı kuralları ifade ettikleri saptanmıştır.

Öğrencilerin cinsiyetlerine göre ürettikleri kural metaforlarına ait soyutluluk ifadelerinin dağılımlarına bakıldığında mutluluk temel duygusunun kız çocuklarında erkek çocuklarına göre yüksek çıkmıştır. Yani cinsiyet değişkeni açısından kız çocuklarının kural kavramına ilişkin algıları daha olumludur.

Çocukların/ öğrencilerin ebeveyn ve öğretmenlerinden talep etikleri birçok şey vardır. $\mathrm{Bu}$ taleplerden karşılanması en zor olanı çocukların duygusal gereksinmelerini karşılamaktır. Burada dikkat edilmesi gereken en önemli nokta çocuğun uyumlu, saygilı, mutlu ve öz disiplin sağlayabilecek yetkinlikte olabilmesini sağlayacak disiplin tekniklerini seçmektir. Doğru disiplin tekniklerinin belirlenmesinde çocukların sahip oldukları mizaç özellikleri de dikkate alınmalıdır (Öğretir, 2017b). Ayrıca yapılan birçok araştırma gösteriyor ki, çocukların kuralları benimsemesi için kuralların çocuklarla birlikte belirlenmesi gerekiyor. Sınıf kuralları belirlenirken çocukların etkin katılımda bulunması kuralların içselleştirilmesinde, problemlerin çözümünde ve kural ihlallerinde oluşan cezaların anlamlandırılmasında etkililiği güçlendirmektedir (Ö̈̆retir ve Demiriz, 2009). 
Uluslararası alanda yapılan çalışmalarda özellikle sınıf ortamında davranışların düzenlemeleri için ortaya konulan metaforlar genellikle olumsuz kelimeler içermiştir. Batı ülkelerinde bile öğretmenlerin sınıf ortamında katı kurallar uygulayabildikleri gözlemlenebilmektedir. Öğretmenler, sınıfta ve okulda yaramazlık yapan öğrencilere karş1 en iyi ve etkili tepkinin ne olduğu ile ilgilenmektedir. Öğrenciler üzerinde yaratacağ 1 caydırıcılıktan dolayı fiziksel cezanın kullanımının öğrenciler üzerinde davranış değişimine yol açabileceği varsayılmaktadır (Landau,2009). Bir başka yöntem ise öğrencilerin davranışlarını istenen yönde değiştirmek için küçümseyici davranma, kınama veya buna benzer yöntemlerin kullanımı da önerilmektedir (Shindler, 2010). Uluslararası çalışmaların birinde, öğrencilerin sınıf ve okul için "hapishane ve cezaevi" gibi metaforlar ürettikleri ve sınıfi "mahkeme salonuna" benzettikleri görülmüştür. Öğrencilerinin sınıf içi ve dışı performansını değerlendirmesi aşamasında sınıf ortamı mahkeme salonuna benzetilmiş ve öğrenciler suçlu, sınıf mahkeme salonu ve öğretmen hakim metaforları ile tanımlanmıştır (Weiner, 2003) 


\section{KAYNAKÇA}

ATEŞ, T.Ö. (2016). “Öğrencilerin Öğretmen ve Okul Metaforları”. International Journal of Contemporary Educational Studies (IntJCES,),June 2016, cilt 2, no. 1, 78-93.

BAL, T. (2005). İlköğretim 4. ve 5. sinif öğretmenlerinin disiplin anlayişlari ve kullandiklari disiplin yöntemleri (Konya ili örneği). Yayınlanmamış Yüksek Lisans Tezi, Selçuk Üniversitesi Sosyal Bilimler Enstitüsü, Konya.

BERK, L. (2013). Çocuk Gelişimi, A.Dönmez (Çevirmen). Birinci Baskı.Ankara.İmge Kitapevi.

BİLIR, Ş., ARI, M.,DÖNMEZ, N., Atik, B. ve San, P. (1991),“Türkiye'nin 16 İlinde 4 - 12 Yaşlar Arasındaki 50.473 Çocuğa Fiziksel Ceza Verme Sıklı̆̆ı ve Buna ilişkin Problem Durumlarının İncelenmesi”, Aile ve Toplum, Y1l: 1 Cilt: 1 Sayı: 1 Mart 1991, 57-70. $\quad$ http://www.cocukgozlemevi.org/wp-content/uploads/50001079455000157031-1-PB.pdf (Erişim 02.10.2017).

BOYACI, A. (2009). "İlköğretim öğrencilerinin disipline sınıf kurallarına ve cezalara ilişkin görüşlerinin karşılaştırmalı olarak incelenmesi (Türkiye-Norveç örneği)", Kuram ve Uygulamada Eğitim Yönetimi, 15(60), 523-553.

ERCAN, L. (2010). "Sınıfta istenmeyen davranışların yönetimi”. L. Küçükahmet (Ed.). Sinıf yönetimi. On Birinci Bask1. Ankara. Pegem Akademi, ss. 183-210.

FORCEVILLE C. (2002). "The identification of target and source in pictorial metaphors". Journal of Pragmatics, 34: 1-14.

GIREN, S. (2016). "Early childhood education teachers' metaphors about play concept for preschoolers", Journal of Theory and Practice in Education, 12(1), 372-388.

GOATLY, A. (2002). "Conflicting metaphors in the Hong Kong special administrative region educational reform proposals", Metaphor and Symbol, 17(4), 263294. doi.org/10.1207/S15327868MS1704_2

GUERREO MCM, VİLLAMIL OS. (2002). "Metaphorical conceptualizations of ESL teaching and learning. Language Teaching Research", 2002; 6(2): 95-120.

HARTER, S. (2006). “The Self”,N. Eisenberg (Ed.), Handbook of ChildPsychology: Social, Emotional, andPersonality Development, New Jersey: John Wiley\&Sons, Inc., 505-560.

JAKOBSON, B., \& WICKMAN, P. (2007). "Transformation thorugh language use: Children's spontaneous metaphors in elenmentary school science", Science \& Education, 16(3-5), 267-289.

KARABAY, S. ve ASİ, D.(2015). "Classroom Rules Usedby Preschool TeachersandChildren'sLevels of AwarenessRelatingto Rules", İø̈nü University Journal of theFaculty of Education, Vol. 16, No 3, 2015, 69-89. DOI: 10.17679/iuefd.16331426

KAYA, HÜSEYINN. (2010). "Metaphors developed by secondary school students towards "Earthquake" concept", Education Research and Review, vol. 5, no. 11, November 2010, 712-718. http://www.academicjournals.org/article/article1379654409_Kaya.pdf (Erişim 02.10.2017).

KORKMAZ, İ. (2003). İstenmeyen Davranışların Önlenmesi: Sınıf Yönetimi. (Ed. ZekiKaya). Ankara:Pegem A Yayınc1lık. s.171-192. 
LANDAU, B. (2009). "Classroom management", Gary Dworkin (eds.), International handbook of research on teachers and teaching, USA: Springer Science and Business Media

MARTINEZ MA, SAULEDA N, HUBER GL. (2001). "Metaphors as blueprints of thinking about teaching and learning". Teaching and Teacher Education, 8: 965-977.

LEWIS, RAMON. (2011). "Classroom Discipline in Australia”, Carolyn M. Everston ve Carol S. Weistein (Ed.), Handbook of Classroom Management: Research, Practice and Contemporary Issues, New York: Routledge, 1193-1214.

MAHİROĞLU, A. ve BULUÇ, M. (2003). "Orta Öğretim Kurumlarında Fiziksel Ceza Uygulamaları", G.Ü. Teknik Eğitim Fakültesi Dergisi, c.1, s.1, 81-95.

MILES, MATTHEW B. ve HUBERMAN, MİCHAEL A. (1994). Qualitative Data Analysis, SagePublication, London.

MURRAY, CHRISSTOPHER ve MARK T. GREENBERG. (2000). "Children's Relationship with Teachers and Bonds with School: An Investigation of Patterns and Correlates in Middle Childhood", Journal of School Psychology, v.38 n.5, Sep-Oct 2000, s. 423-45.

ÖĞRETIR, AYŞE D. ve SERAP DEMIRİZ (2007). "Alt ve Üst Sosyo-Ekonomik Düzeydeki 10 Yaş Çocuklarının Anne Tutumlarının İncelenmesi”, Kastomonu Eğitim Dergisi, cilt 15, no.1, 105.122.

ÖĞRETIR-ÖZÇELIK, AYŞE DİLEK. (2017a). "Investigating and comparing the relationship between parental monitoring types and perceived parentingstyles of theTurkishstudents", International Journal of Human Sciences (Uluslararas1 İnsan Bilimleri Dergisi), vol. 14, no.1., 2017, 331-345. https://doi.org/10.14687/jhs.v14i1.4400

https://www.j-humansciences.com/ojs/index.php/IJHS/article/view/4400 (Erişim 18.12.2017).

ÖĞRETIR-ÖZÇELIK, AYŞE D. (2017b). "The Comparative Analysis of the Perceptions of Parental Styles and Attitudes and Parental Attachment of University Students", International Journal of Psycho-Educational Sciences, vol. 6, no.1, April 2017, 23-35. DOI: https://doi.org/10.14687/jhs.v14i1.4400

http://journal.kie.university/wp-content/uploads/2017/06/612017.pdf (Erişim 18.12.2017).

ÖĞRETIR-ÖZÇELIK, AYŞE D. (2017c). "Examination of Social Skills of Pre-School Children", European Journal of Educational Studies, vol. 3, no.2, 80-97. doi: 10.5281 /zenodo. 244577

https://oapub.org/edu/index.php/ejes/article/view/459/1246 (Erişim 18.12.2017).

ÖRÜCÜ, D. (2012). "İlköğretim Sınıf Öğretmenlerinin Sınıfa ve Sınıf Yönetimine ilişkin Metaforik Bakışları: Karşılaştırmalı bir Durum Çalışması”,Elementary Education Online, 11(2), 342-352.http://ilkogretim-online.org.tr

PERRY C ve COOPER M. (2001). "Metaphors are good mirrors: Reflecting on change for teacher educators", Reflective Practice, 2(1): 41-52.

SALK. L.(1990). Çocuğun Duygusal Sorunları. çev.Erzem Onur, 1.bask1, İstanbul: Remzi.

SHINDLER, J. (2010). Transformative classroom management, USA. Jossey-Bass. 
TÜZEL, EMEL ve ŞAHINN, DEMET (2014). "İlköğretim Birinci Kademe Öğrencilerinin Okul Yöneticilerine İlişkin Metaforları",Adlyaman Üniversitesi Sosyal Bilimler Enstitüsü Dergisi, Y11: 7, Say1: 17, Agustos 2014, 355396.DOI: http://dx.doi.org/10.14520/adyusbd.736

UYSAL, H.,ALTUN, S. ve AKGÜN, E.(2009). "Okulöncesi Öğretmenlerinin Çocukların İstenmeyen Davranışları Karşısında Uyguladıkları Stratejileri”, Ege Üniversitesi 18. Eğitim Bilimleri Kurultayı Bildiriler, 1-3 Ekim 2009-Kuşadas1.

YALÇIN,M.,ERGINNER, A. (2012). İlköğretim Okullarında Okul Müdürüne İlişkin Metaforik Alg1lar. Journal of TeacherEducationandEducators Öğretmen Eğitimi ve Eğitimcileri Dergisi Volume/Cilt 1, Number/Say1 2, 2012, 229-256

YAMAN, E. ve GÜVEN, N. (2014). "Öğrencilerin motivasyon düzeyine etki eden önemli bir kavram: Ödül ve ceza”, Vol: 11 Issue: 1,International Journal of Human Sciences (JHS), 1163-1177. http://dx.doi.org/10.14687/ijhs.v11i1.2782

YILDIRIM, A. \& ŞİMŞEK, H. (2005). Sosyal Bilimlerde Nitel Araştırma Yöntemleri, Ankara: Seçkin.

WEINER, B. (2003).” The classroom as a Courtroom", Social Psychology of Education,6:315. 